Neth. J. Agric. Sci., 15 (1967) : 198-206

\title{
Preliminary results of a grazing trial in the Syrian Steppe
}

\author{
J. P. H. van der Veen
}

Range management and fodder production, Food and Agriculture Organization of the United Nations, P.O. Box 247, Alexandria, U.A.R.

Received 21 September, 1966

\section{Summary}

A grazing trial was started in 1963 at the Wadi Al A'azib Range and Sheep Experiment Station in the N.W. part of the Syrian Steppe to compare the effect of three stocking rates $(9.0,6.0$ and 4.5 ha per sheep) on animal production and on the composition and density of the vegetation. Average yields were somewhat lower in the high stocking rate treatment as compared with the low stocking rate treatment in 1966, which was a drought year. Studies on the comparative effect of the stocking rates on the vegetation are inconclusive. Pending further experimentation the preliminary conclusion is that a stocking rate of 4.5 ha per adult ewe on the basis of yearround grazing with provision of supplement feed in periods of extreme drought or cold does not lead to serious depletion of grazeable herbage.

\section{Introduction}

\section{General}

The Syrian Steppe, which covers an estimated area of about 8 million hectares or $44 \%$ of Syria's total land surface, is used for extensive grazing, mainly by sheep. A nomadic pattern is followed with a largely eastward migration during late autumn into the steppe- and desert areas and a largely westward migration to the agricultural areas in early summer. Male lambs, culled ewes, milk products and wool (carpet type) are marketed.

During years of good rainfall the sheep population increases rapidly, followed by sharp declines in drought years. However, the availability of motorized transport to carry feed supplies in emergencies and water when needed, better veterinary services, increased provision of pumped water for drinking are factors disturbing the balance set by nature between available grazing and sheep numbers.

Realizing the danger of increased depletion of the range resource through overgrazing, the Syrian Government in 1959 established the Wadi Al A'azib Range and Sheep Experimental Station covering an area of 25,000 ha. The station was stocked with several flocks of Awassi sheep, the fat-tail breed found in the steppe areas of Syria and neighbouring countries.

\section{Location}

The station is located in the N.W. part of the Syrian steppe at a distance of $120 \mathrm{~km}$ N.E. of Hama. About $50 \mathrm{~km}$ south of the station is a low range of mountains from where after heavy rains run-off water drains into a valley which passes through the 
experimental area. The station derives its name from this valley. The altitude of the experimental area is about $450 \mathrm{~km}$ above sea level. Ecological and climatological conditions at the station are generally similar to those of an area of about 1.5 million ha in the Syrian Steppe. However, the vegetation at the station is presently: in a much better condition due to protection, four good rainfall years, and only light grazing since 1960.

\section{Climate}

The climate is characterized by hot, dry summers and cool winters. Rains fall from November till June; December, January and February being the months with the highest rainfall. Average rainfall per month for the period 1957-1966 was as follows:

Sept. Oct. Nov. Dec. Jan. Febr. March April May June Total

$\begin{array}{lllllllllll}0.2 & 3.6 & 13.9 & 20.5 & 36.1 & 21.4 & 18.5 & 29.6 & 7.4 & 0.7 & 150.5 \mathrm{~mm}\end{array}$

Sharp fluctuations in rainfall occur from year to year; the lowest recorded since 1957 was $61.9 \mathrm{~mm}$ in the 1959-1960 season, the highest $231.6 \mathrm{~mm}$ in the 1961-1962 season. The average maximum temperature of the hottest month is $38^{\circ} \mathrm{C}$, the average minimum temperature of the coldest month is between $1^{\circ}$ and $2^{\circ} \mathrm{C}$.

\section{Vegetation}

Phyto-geographically the area is considered as belonging to the Irano-Turanian Region, part of the plants originating from the Mauritanian Steppes element of that region, whereas other species and genera belong to the Mesopotamian and Irano-Anatolian sub-regions. Some Mediterranean elements are also represented.

The vegetation can best be described as a dwarf shrub steppe. The climax would probably be a tall grass steppe (with Stipa spp. dominant) especially on the deeper loess-like soils.

Five vegetation units are distinguished at the Wadi Al A'azib experimental range:

a) Valley streambed and floodplain vegetation on alluvial silt, consisting of a dense stand of Haloxylon articulatum as dominant dwarf shrub, with Poa sinaica, Carex stenophylla var. pachystylis and annuals forming a dense ground cover. Carex is far denser than Poa, while the annuals, comprising a.o. Schismus arabicus, Koeleria phleoides, Malva aegyptiaca and $M$. rotundifolia, Ami majus, Hordeum murinum and Bromus spp. are very dense after water has run through the valley in autumn or winter.

b) Valley terrace vegetation (on higher part of floodplain, consisting of fluviatile deposits as in $a$, but now only flooded after exceptionally heavy rains in catchment area). Thin stand of Haloxylon articulatum as only dwarf shrub. The ground cover consists of a denser stand of $P o a$ sinaica but a less dense stand of Carex than in $a$, with a dense stand of annuals in good rainfall years only. However, the number of annual species is much more limited than in a. Main annuals are Schismus arabicus and Koeleria phleoides; Plantago spp. being relatively dense in some years.

c) Artemisia herba-alba association on marly soils. Other dwarf shrubs include Noea mucronata and Salsola spinosa. Poa sinaica can be quite dense, although generally less than in $b$ and $d$. Carex stenophylla var. pachystylis occurs only very sparsely or is absent. The density of annuals is low. A potentially important species from the point of view of range management is Onobrychis olivieri, a perennial legume. d) Haloxylon articulatum association in small valleys and on hill-slopes with relatively deep aeolian deposits on limestone. Sometimes presence of Artemisia herba-alba 
and Noea mucronata; few other dwarf-shrub species; in some locations Stipa barbata. Relatively dense stand of Poa sinaica and, especially in small valleys and lower parts of slopes, of Carex stenophylla var. pachystylis. Annuals (mainly Schismus arabicus, locally Stipa capensis) dense in certain years.

e) Haloxylon articulatum-Noea mucronata association on shallow, stony, grey desert soil on folded limestone hills. Poa sinaica, Carex and annuals are generally less dense than in vegetation unit $d$. A greater variety of dwarf-shrub species is found than in any of the other vegetation units (e.g. Artemisia herba-alba, Teucrium polium, Achillea membranacea, Salsola vermiculata, Salvia spp.). The density of dwarf-shrubs is generally greater than in $b$ and $d$.

\section{Grazing pattern}

When the sheep arrive in the steppe area in autumn, the main source of grazing is provided by the dried-up annuals from the previous season and the dwarf-shrubs, which are mostly dry or drying. Poa sinaica, followed by Carex, is grazed as soon as the new growth starts following the beginning of the winter rains. Poa and Carex are the main sources of grazing during the first two to three months of the winter (Dec.-Feb.), while from March till June annuals provide the bulk of grazeable herbage, Poa quantitatively taking the second place. Flocks which do not leave for the cereal aftermath fields use dried-up annuals, Poa flowerstalks and certain dwarf shrubs as main herbage intake in June and July, while during August, September and October dwarf shrubs are both quantitatively and qualitatively the more important constituents of herbage intake, supplemented by dried-up annuals and dry Poa flowerstalks in years when spring growth was abundant.

\section{Grazing trial}

\section{Purpose}

As part of the experimental work a trial was initiated in 1963 to compare three different stocking rates. The aim is to have data which can be used as a basis for more detailed studies to determine the stocking rate giving the highest sustained economic production. Moreover data obtained are to serve as a guide for estimations of the carrying capacity of larger parts of the Syrian steppe until more experimental data are available.

\section{Experimental procedure}

The three stocking rates are 9.0, 6.0 and 4.5 ha per adult ewe; they are referred to as treatment A, B and C, respectively. Three areas of 600 ha each $(4 \times 1.5 \mathrm{~km})$ were chosen as grazing paddocks in such a way that the three main vegetation types are represented approximately equally in each paddock and so that the differences in distances to the two watering points are as small as possible. The flock composition in the three treatments is as follows:

$$
\text { Ewes over } 2 \text { years Ewes of } 2 \text { years }
$$

Treatment A Treatment B Treatment $\mathrm{C}$
Yearlings 
In the first two years the number of ewes over 2 years was somewhat lower and the numbers of 2-year old ewes and yearlings somewhat higher due to non-availability of the right number of adult ewes. The sheep are weighed monthly; lambs are weighed at birth and then monthly; each flock's milk production is weighed daily and individual milk yields per ewe are weighed once a month; at shearing the wool of each animal is weighed.

The trend of the vegetation under the three stocking rates is measured by means of a cluster of three permanent transect lines in each of the three main vegetation units in the three paddocks. Frequency percentages of vegetation components are measured each spring through the loop transect method; the transect lines being $25.50 \mathrm{~m}$ long, the loop readings $25 \mathrm{~cm}$ apart and the diameter of the loop $1.8 \mathrm{~cm}$.

In 1964 sample clippings of grazeable herbage were made in spring and autumn inside and outside of $3 \times 4 \mathrm{~m}$ exclosures, with 3 exclosures in each of 4 vegetation units per paddock. The exclosures are changed to new sites after the autumn clipping. The difference in weight between inside and outside clippings provides an indication of herbage consumption. No clippings were carried out in 1965 and in the spring of 1966 due to shortage in personnel and very poor spring growth, respectively.

\section{Sheep management}

Breeding takes place from about the middle of July till about the end of August. Lambing starts around the middle of December.

Weaning starts at the age of $2-21 / 2$ months. For about a month after the beginning of weaning the lambs are allowed to suckle during 1-2 hours following the afternoon milking. Weaning is thus completed at the age of 3-31/2 months. In June milking is reduced to once a day, while shortly before drying it is further reduced to once every 2-3 days.

Male lambs are removed from the paddocks in June. The flocks are culled at about the same time, the number of ewe lambs exceeding the number needed for replacement being taken off the paddocks.

Supplement feed is only provided in times of emergency. As a result of an abnormal cold spell early in 1964 supplements were given during 23 days. During the first 13 days $347 \mathrm{~g}$ sugarbeet pulp and $347 \mathrm{~g}$ wheat bran were given daily per ewe. During the following 10 days differential feeding was practiced, the animals in treatments $A$, $\mathrm{B}$ and $\mathrm{C}$ receiving respectively 347,231 and $173 \mathrm{~g}$ of pulp and of bran per head per day. Total amounts received were of pulp and bran each: $8 \mathrm{~kg}, 6.8 \mathrm{~kg}$ and 6.2 $\mathrm{kg}$ per head in treatments $\mathrm{A}, \mathrm{B}$ and $\mathrm{C}$, respectively.

In the summer of 1966 supplement feeding had to be resorted to as a result of poor grazing conditions, due to drought in the preceding winter and spring. The sheep in all treatments received equal amounts per head. From 20/5/66 till 10/6/66 $200 \mathrm{~g}$ oats and $100 \mathrm{~g}$ cotton seed were given per head per day, which was increased to $300 \mathrm{~g}$ oats and $100 \mathrm{~g}$ cotton seed cake on $10 / 6$; while on $20 / 8200 \mathrm{~g}$ vetch straw was added to the daily ration. Till the first of September, which is the beginning of the 1966-1967 experimental year, the animals had thus received $29.1 \mathrm{~kg}$ oats, $10.4 \mathrm{~kg}$ cotton seed cake and $2.2 \mathrm{~kg}$ vetch straw per head.

It is, in this respect, of interest that the animals of the grazing trial started to get in heat about a month later than other animals at the station which had received supplements in the preceding fall and early winter and greater rations in the summer. 


\section{Results during 1963-1966}

\section{Climate and grazing conditions}

Due to good rainfall in the 1962-1963 winter and light grazing, a rather dense stand of dried-up annuals was available for grazing in the autumn of 1963. Winter rains, however, started late. Because of this, growth of Poa sinaica and Carex stenophylla var. pachystylis did not start till about the middle of December. Growth was checked, however, by a cold wave lasting from late December till early February, which also delayed germination and growth of the annuals. Due to favourable moisture conditions and a rapid rise in temperatures spring growth was exceptionally vigorous. The stand of Schismus arabicus was very dense. Most Poa sinaica flowerstalks had bulbils in viviparous flowers.

In the 1964-1965 season green herbage was available earlier but the density and vigour of the vegetation in the spring were less than in the previous year. Notably the density of annuals was less. June rains furthermore reduced the nutritive value of the 'standing hay'. Grazeable herbage resources in the autumn were therefore rather low. The sheep browsed dwarf shrubs which normally are not taken at this time of the year, such as Noea mucronata. Haloxylon articulatum was grazed to a greater degree than in other years.

Winter rains in the 1965-1966 season again started late. The total rainfall for the season was well below average (total rainfall in the three seasons of the 1963-1966 period was 199.5, 206.6 and $103.7 \mathrm{~mm}$, respectively). Growth of Poa and Carex was poor, germination percentage and growth of most annuals was poor. An exception was formed by the floodplain where grazing conditions improved in early spring because of a flood. Towards the end of May, however, the sheep had grazed off most of the grazeable herbage in the respective parts of the floodplain in each paddock and concentrate supplements had to be provided.

\section{Treatment effect on animal production}

Relevant animal production data are given in Table 1. Average liveweight of ewes over 2 years at the end of May is given as an approximation of liveweight of culled ewes. Late May weights of male lambs and ewe lambs are given since this is the approximate time for offtake for slaughter and for replacement.

In Fig. 1 curves show the weight trend of ewes over 2 years' age in treatments A and C for the periods Sept. 1963-August 1964 and Sept. 1965-July 1966. In 19631964 the majority of the lambs were born between Dec. 20th and Jan. 24th (the mean lambing date being Jan. 10th), whereas in the 1965-1966 season the main lambing period was from about Dec. 15th till Jan. 30th (mean lambing date Jan. 6th). The drop in weight in December, January and in the 1963-1964 season also in February is due to lambing. The rapid weight gains in the spring are due to the availability of green herbage. In the 1964 season this was much more abundant than in 1966, which is reflected in faster gains in 1964 as can be seen in the curves. The spring gains in 1964 started later than in 1966, because the cold spell in early 1964 retarded the new growth of the vegetation. It is mainly during the period of rapid weight gains in the spring that fat is accumulated in the tails to help the animals overcome the period of poor grazing in late summer and autumn.

A second reduction in weight takes place in May. This is due to shearing and coincides with the drying up of most ephemerals. The more rapid gains in June 1966 as compared with June 1964 are due to the feeding of supplement feed (concentrates) 
Table 1 Production data, Awassi sheep. Wadi Al A'azib grazing trial 1963-1966. Means in $\mathrm{kg}$ per sheep.

\begin{tabular}{|c|c|c|c|c|}
\hline & & \multicolumn{3}{|c|}{ Treatment } \\
\hline & & $A$ & $B$ & $C$ \\
\hline \multirow[t]{3}{*}{ Milk ${ }^{1}$} & 1964 & 57.6 & 70.6 & 57.6 \\
\hline & 1965 & 63.1 & 74.6 & 69.2 \\
\hline & 1966 & 29.0 & 23.1 & 23.8 \\
\hline \multirow{2}{*}{$\begin{array}{l}\text { Male lambs } \\
\text { Liveweight } 28 \text { May }\end{array}$} & 1964 & 40.2 & 38.5 & 39.4 \\
\hline & 1966 & 29.4 & 26.6 & 25.0 \\
\hline \multirow{2}{*}{$\begin{array}{l}\text { Ewe lambs } \\
\text { Liveweight } 28 \text { May }\end{array}$} & 1964 & 32.8 & 33.6 & 35.2 \\
\hline & 1966 & 27.6 & 24.8 & 24.9 \\
\hline \multirow{2}{*}{$\begin{array}{l}\text { Ewe lambs } \\
\text { Liveweight } 28 \text { June }\end{array}$} & 1965 & 35.0 & 34.6 & 30.0 \\
\hline & 1966 & 27.8 & 27.9 & 25.4 \\
\hline \multirow{3}{*}{$\begin{array}{l}\text { Ewes over } \\
2 \text { years } 28 \text { May }\end{array}$} & 1964 & 51.4 & 48.1 & 47.7 \\
\hline & 1965 & 46.7 & 45.1 & 44.4 \\
\hline & 1966 & 42.2 & 38.8 & 39.5 \\
\hline \multirow{3}{*}{$\begin{array}{l}\text { Wool, unwashed } \\
\text { ewes over } 2 \text { years }\end{array}$} & 1964 & 2.67 & 2.84 & 3.19 \\
\hline & 1965 & 3.75 & 2.95 & 3.05 \\
\hline & 1966 & 2.03 & 2.00 & 2.15 \\
\hline \multirow{3}{*}{$\begin{array}{l}\text { Wool, unwashed } \\
\text { ewes of } 2 \text { years }\end{array}$} & 1964 & 3.02 & 3.00 & 3.24 \\
\hline & 1965 & 3.75 & 2.95 & 3.87 \\
\hline & 1966 & 2.36 & 2.19 & 2.18 \\
\hline \multirow{3}{*}{$\begin{array}{l}\text { Wool, unwashed } \\
\text { yearling ewes? }\end{array}$} & 1964 & 4.15 & 4.27 & 4.45 \\
\hline & 1965 & 4.91 & 3.87 & 4.08 \\
\hline & 1966 & 2.36 & 2.85 & 2.72 \\
\hline
\end{tabular}

1 Average production of all ewes in the flock, thus including ewes which had not lambed; production per milking ewe was considerably higher especially in 1964

2 The sheep are not shorn until they are yearlings

from the end of May onwards, which was necessitated by the poor nutritional state of the animals resulting from the drought. The animals generally continue to make slight gains after breeding in July-August.

The main differences in production per animal were found in 1966, when average milk output, weight of male and female lambs and of adult ewes was higher in the light stocking rate treatment. Production per ha, meanwhile, remained highest with the highest stocking rate, as shown in Table 2 for the years 1964 and 1966.

\section{Treatment effect on the vegetation}

Due to accidental removal of transect lines stakes in treatment $B$ and part of the stakes in treatment $\mathrm{C}$ in 1965, detailed continuous comparative data to determine trend differences are only available from vegetation unit $e$ in treatments $\mathrm{A}$ and $\mathrm{C}$. The disturbed transect lines were re-established in 1966. Although detailed comparisons between the 1964 and the 1966 data can not be made, large differences still indicate approximate trends since the new lines are close to the original sites.

The plant density decreased in all treatments from 1964 to 1966 mainly due to a 
decreased density of annuals. In vegetation unit $e$ the density of dwarf shrubs increased in treatment A from $7 \%$ in 1964 to $12 \%$ in 1966, but remained about constant in treatment $\mathrm{C}$ from $7 \%$ in 1964 to $9 \%$ in 1965 but had decreased to less than $2 \%$ in 1966. Two valuable grazing species made their appearance in the transect lines of treatment $\mathrm{A}$ in this vegetation unit: one seedling of Salsola vermiculata in 1965 and a Stipa barbata seedling in 1966.

While the all-over plant density decreased, the density of Carex stenophylla var. pachystylis increased, especially in vegetation types $b$ and $d$. In treatments $\mathbf{A}$ and $\mathbf{B}$ the increase in Carex was greater than in treatment C.

Although several interesting features were obtained from the transect line data, no definite conclusions can be made with regard to the trend of the vegetation under the impact of the three stocking rates. Data would be needed over a longer period of time to know, for example, whether the trend difference of dwarf shrubs with high and low stocking rates as described above would persist. Another factor requiring further study is whether the increased density of Noea mucronata, a dwarf shrub of rather low value for sheep grazing, would in the long run cause a decrease in more valuable species under the low stocking rate in vegetation unit e. Visual observations

Table 2 Meat (carcass), milk and wool production. Wadi Al A'azib grazing trial 1964 and 1966.

\begin{tabular}{|c|c|c|c|c|c|c|c|c|c|c|}
\hline & \multicolumn{10}{|c|}{ Carcass weight 1 (in $\mathrm{kg} / 100 \mathrm{ha}$ ) } \\
\hline & \multicolumn{2}{|c|}{ male lambs } & \multicolumn{2}{|c|}{ ewe lambs 2} & \multicolumn{2}{|c|}{ culled ewes } & \multicolumn{2}{|c|}{$\begin{array}{c}\text { total } \\
\text { including } \\
\text { ewe lambs }\end{array}$} & \multicolumn{2}{|c|}{$\begin{array}{c}\text { total } \\
\text { excluding } \\
\text { ewe lambs }\end{array}$} \\
\hline & 1964 & 1966 & 1964 & 1966 & 1964 & 1966 & 1964 & 1966 & 1964 & 1966 \\
\hline Treatment A & 95 & 64 & 43 & 29 & 38 & 31 & 176 & 124 & 133 & 95 \\
\hline Treatment B & 135 & 85 & 65 & 37 & 54 & 43 & 254 & 165 & 189 & 128 \\
\hline Treatment $\mathrm{C}$ & 185 & 108 & 93 & 52 & 71 & 59 & 349 & 219 & 256 & 167 \\
\hline
\end{tabular}

\begin{tabular}{|c|c|c|c|c|}
\hline & \multicolumn{4}{|c|}{ Production $^{3}$ (in $\mathrm{kg} / 100 \mathrm{ha}$ ) } \\
\hline & \multicolumn{2}{|c|}{ milk } & \multicolumn{2}{|c|}{ wool } \\
\hline & 1964 & 1966 & 1964 & 1966 \\
\hline Treatment A & 551 & 257 & 37 & 25 \\
\hline Treatment B & 914 & 305 & 58 & 45 \\
\hline Treatment $\mathrm{C}$ & 998 & 421 & 84 & 54 \\
\hline
\end{tabular}

1 Based on average production per animal and actual percentage of surviving 5-month old lambs. Carcass weight of male lambs adjusted for estimated required ram replacements. Meat from culled rams not included. Carcass weight is estimated at $45 \%$ of live weight for culled ewes and $53 \%$ for lambs. A culling rate of $15 \%$ of all adult ewes, or $25 \%$ of ewes over 2 years is assumed with the flock composition of the experiment.

2 Ewe lambs in excess of replacement of culls and death losses of ewes. Death loss estimated at $4 \%$ in 1964 and $6 \%$ in 1966 (actual death losses in experiment were lower). In Syria ewe lambs are not slaughtered. All are used for replacement, and flock increase or sale for breeding. Ewe lambs are included here to show potential meat production with constant sheep population.

3 Milk production based on total daily milk recorded per flock. Shearing was done by hand in 1964 and by machine in 1966. Hand-shearing would have given lower figures in 1966. 
Table 3 Average yields, fresh and air-dry herbage in $\mathrm{kg} / \mathrm{ha}$. One spring and one autumn clipping of grazeable herbage inside exclosures. Wadi Al A'azib grazing trial 1964.

\begin{tabular}{|c|c|c|c|}
\hline & & Fresh & Air-dry \\
\hline Vegetat & unit $a$ & 3129 & 1724 \\
\hline ", & , $b$ & 1126 & 758 \\
\hline , & , d & 1312 & 849 \\
\hline$"$ & $" e$ & 859 & 608 \\
\hline
\end{tabular}

gave the impression that the density and composition of the vegetation under the 4.5 ha per sheep stocking rate did not regress provided feed supplements were given in drought years.

Average yields of air-dry herbage inside the exclosures in 1964 are given in Table 3. Air-dry matter was over $50 \%$ of green matter except in vegetation unit $a$ where the spring clipping contained a relatively large proportion of succulent annuals such as Hordeum murinum.

A great variability was found in herbage yields from the replicated sample clippings inside and outside of small exclosures in 1964. A larger number of replications is needed for a statistical evaluation of the data. The differences between the average yields inside and outside of the exclosures is given in Table 4.

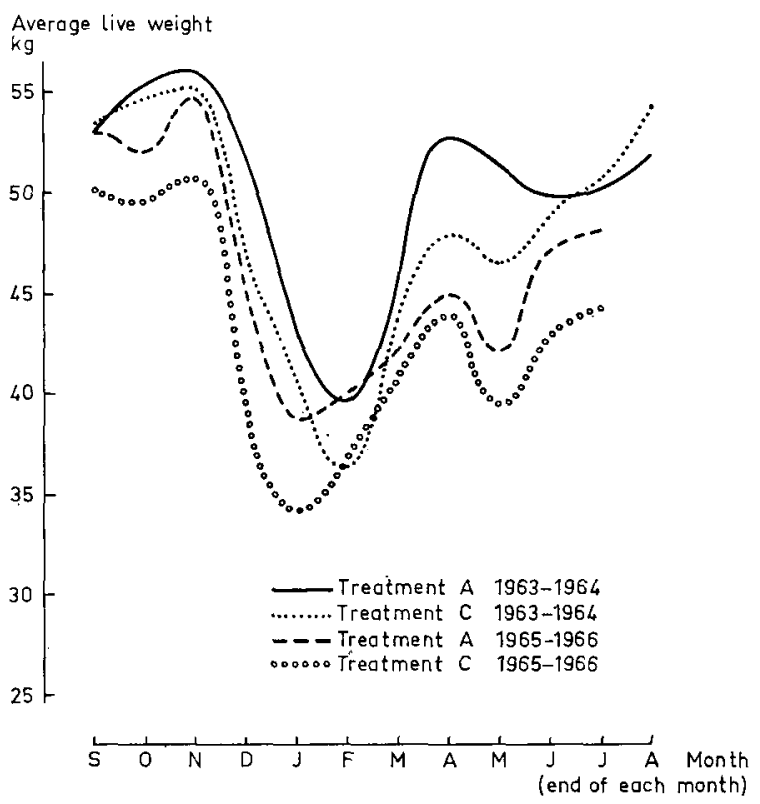

Fig. 1 Liveweight trend of Awassi ewes over 2 years' age, 1963-1964 and 1965-1966 in treatments $A$ and $C$. Wadi Al A'azib grazing trial. 
Table 4 Mean difference in air-dry herbage from sample clippings (grazeable herbage only), in \% of herbage inside the exclosure. One spring and one autumn clipping. Negative sign indicates higher yield of herbage outside the exclosure. Wadi Al A'azib grazing trial 1964.

\begin{tabular}{|c|c|c|c|c|}
\hline & & \multicolumn{3}{|c|}{ Treatment } \\
\hline & & $A$ & $B$ & $C$ \\
\hline \multicolumn{2}{|c|}{ Vegetation unit $a$} & 2 & 0.3 & 30 \\
\hline, &,$\quad b$ & 35 & 3 & 19 \\
\hline$"$ & $" d$ & -4 & 14 & -10 \\
\hline$"$ & $" e$ & 17 & 15 & 23 \\
\hline
\end{tabular}

The data indicate that in 1964 a large part of the grazeable herbage in all treatments remained ungrazed, which was confirmed by visual observations. Visual observations indicate that a much larger part of the vegetation was grazed in 1965 , due mainly to the decreased density of annuals, and in 1966 spring herbage was too short and too sparse for clipping.

\section{Conclusion}

Average output of meat, milk and wool per animal was not decreased greatly in the high stocking rate treatment as compared with the lower stocking rates, although average yields in the high stocking rate treatment dropped somewhat below the level of the light stocking rate treatment in 1966, which was a drought year.

The study of the effect of the different stocking rates upon the vegetation is still inconclusive. However, the data from the transect lines supplemented by visual observations seem to justify the preliminary conclusion that no serious depletion of the vegetation would be caused by the high stocking rate, provided supplement feed is given in emergencies (extreme cold or drought periods). Further research is needed to substantiate this conclusion and to study the effects of various stocking rates with and without supplement feeding as a normal practice during the pre- and post-lambing periods.

\section{Acknowledgements}

The author wishes to express his appreciation for the cooperation of various field workers and staff members of the Steppe Department of the Ministry of Agriculture, Syrian Arab Republic who were connected with the execution of the experiment. Special mention is made of the work of Mr. A. Masri, Chief, Pasture Section in the Department, who is in charge of general supervision and direction of the trial. His knowledge of the vegetation and his understanding of range problems in the area were of great value.

Furthermore, the writer is indebted to the Ministry of Agriculture in the Syrian Arab Republic, and to the Food and Agriculture Organization of the United Nations, who kindly consented to the publication of this article. 